\title{
Rousseau, George Moore, and the Ethics of Confession
}

\section{Elizabeth Grubgeld}

\section{Q OpenEdition \\ 1 Journals}

\section{Electronic version}

URL: http://journals.openedition.org/etudesirlandaises/4855

DOI: 10.4000/etudesirlandaises.4855

ISSN: 2259-8863

\section{Publisher}

Presses universitaires de Rennes

\section{Printed version}

Date of publication: 15 June 2016

Number of pages: 143-154

ISBN: 978-2-7535-5091-9

ISSN: 0183-973X

\section{Electronic reference}

Elizabeth Grubgeld, «Rousseau, George Moore, and the Ethics of Confession », Études irlandaises [Online], 41-1 | 2016, Online since 15 June 2018, connection on 20 April 2019. URL : http:// journals.openedition.org/etudesirlandaises/4855; DOI : 10.4000/etudesirlandaises.4855 


\title{
Rousseau, George Moore, and the Ethics of Confession
}

\author{
Elizabeth GrubGELD \\ Oklahoma State University
}

Abstract

George Moore always claimed a literary paternity more French than Anglophone, and although the degree of his debt to Jean-Jacques Rousseau remains a matter of speculation, a comparison of their autobiographies yields a set of important questions about the ethics of life writing. Inquiries into the ethics of nonfiction have thus far concerned the representation of others and questions of privacy. However, the secular confessions of Rousseau and George Moore also elicit our attention to the manner by which narrative structures both allow and avoid moral self-inquiry.

Keywords: George Moore, Jean-Jacques Rousseau, autobiography, ethics, Franco-Irish literary relations

\section{Résumé}

George Moore s'est toujours réclamé d'une paternité littéraire française plutôt qu'anglaise, et quoique la portée de sa dette envers Jean-Jacques Rousseau relève de la conjecture, une comparaison entre leurs autobiographies soulève des questions importantes en matière d'éthique de l'écriture de soi. Jusqu'à présent, les travaux d'investigation portant sur l'éthique des ouvrages de non-fiction n'ont fait qu'interroger la représentation des autres et la question de la vie privée. Pourtant, les confessions profanes de Rousseau et de Moore attirent notre attention sur la manière dont certaines structures narratives permettent et évitent à la fois l'interrogation morale de soi-même.

Mots clés : George Moore, Jean-Jacques Rousseau, autobiography, éthique, relations littéraires franco-irlandaises

Although most readers immediately think of Esther Waters when they think at all of George Moore, the novel is in many ways atypical of his work. Moore repeatedly claimed a literary paternity more French than English, and whereas the vast array of characters from urban and rural life reflects his reading of Balzac and those scenes that made the novel's debut a matter of scandal reveal his debts to Zola, Moore identified this work "as characteristically English as Don Quixote is Spanish" ${ }^{1}$. In addition to a place among his contemporaries as a respected English novelist, Esther Waters brought to her Irish author an aura of moral seriousness at

1. George Moore, Esther Waters, New York, Boni and Liveright (Carra Edition), 1922, p. VI. 
variance with his reputation as an iconoclastic provocateur. Unlike Esther Waters, Moore's autobiographies were for decades understood as little more than salacious gossip: witty and elegantly written but without intellectual or moral complexity. Yet in those memoirs, which themselves have little precedent within the British autobiographical tradition, Moore deploys gossip and satiric comedy as a mode of confession through which to explore challenging questions about art and human relations. As much as his memoirs differ from his best-known novel, they are equally concerned with ethical problems, and Moore locates one of his most crucial confessions in a memory of the servant woman whose conversation, he said, provided the necessary background for Esther Waters. His memories of "awful Emma", in conjunction with those of the painter Clara Christian and his mother, Mary Blake Moore, offer three foci from which to explore his treatment of a genre most closely associated with both the "God-tortured soul2", as he calls St. Augustine, and more significantly for Moore, Jean-Jacques Rousseau.

Although the English language progenitors of George Moore's autobiographies include Thomas Carlyle's Sartor Resartus and the eighteenth-century picaresque novels that filled the libraries of Anglo-Ireland, George Moore may also be one of the children whom Jean-Jacques Rousseau notoriously abandoned in their infancy ${ }^{3}$. Rousseau submitted his singular life narrative as part of his larger philosophical argument about the inherent innocence of human beings and the supremacy of feeling over other human attributes. Correspondingly, works like Confessions of a Young Man (1888) and Hail and Farewell (1911-13) tender confession as evidence in support of serious arguments about the nature of art and the even more serious problem of how we are to live in this world: the matter of ethics, which Paul John Eakin has named "the deep subject of autobiographical discourse ${ }^{4 "}$. My purpose here, however, is not to trace influence but to suggest that even as he echoes certain aspects of Rousseau's peripatetic structure and his naive and sometimes outlandish persona, Moore's approach to the confession is antithetical to Rousseau's. To analyze Moore in light of Rousseau is to probe that "deep subject" of which Eakin speaks and to discover in Moore an ethical positioning far different from Rousseau's and far different from either the studied earnestness of Esther Waters or the "glacial gaze of the serpent" with which one of his most

2. George Moore, Confessions of a Young Man, Susan Dick (ed.), Montreal, McGill-Queen’s University Press, 1972, p. 35 .

3. In her 1979 article "Where was Rousseau?" Phyllis Grosskurth explores the absence of Rousseau's confessional mode among nineteenth-century British autobiographies. Despite the recovery of many forgotten Victorian memoirs in the decades since her article appeared, her claims remain accurate. Moore is one of the few Anglophone writers of his period to engage Rousseau or his model of autobiography. Phyllis Grosskurth, "Where was Rousseau", in George Landow (ed.), Approaches to Victorian Autobiography, Athens, Ohio University Press, 1979, 26-38.

4. Paul John Eakin, "Introduction”, in Paul John Eakin (ed.), The Ethics of Life Writing, Ithica, Cornell University Press, 2004, p. 6. 
fervent admirers, Ford Madox Ford, nevertheless charged him 5 . Inquiries into the ethics of nonfiction have thus far primarily concerned the representation of others and questions of privacy. However, if, as Arthur Frank has argued in relation to illness narratives, "self-stories are told to make sense of a life that has reached some moral juncture ${ }^{6 "}$, then readers concerned with the ethics of narration must look carefully at those junctures to ask how narrative structures both allow and avoid moral inquiry.

Rousseau changed the shape of the confessional mode and brought it into a secular universe, one which privileged and continues to privilege the inner life of the individual for its own sake and for the sake of the story told. Through his career-long addiction to the art of self-narrative, Moore too changes and makes further problematic the shape of this evolving genre. Like most children, and particularly problem children, Moore needed to distance himself from Rousseau to assert his originality. It is difficult to ascertain just how much he knew of Rousseau's Confessions before writing his. When he claimed in the 1917 preface to his latest revision of Confessions of a Young Man that he had not read Rousseau before writing his book and "wrote without a model", he was telling at least a partial truth $^{7}$. Despite its currency among Moore's friends in Paris, when W.K. Magee decades later gave him a copy of The Confessions in English, he observed that Moore had a much easier time with the translation than with the $18^{\text {th }}$ century French $^{8}$. Rousseau's irony is not easily discernible in an English translation, dependent as it is on stylistic parody and allusion, and it is unlikely to have been apparent to someone whose French was serviceable but not conversant in the wide range of textual echoes Rousseau employs. As in Moore's work, what Rousseau has to say is inextricably embedded in how he says it: the style is also content, and the irony with which both men portray their younger selves depends upon a reader's recognition of the nuances of language as well as instances of parody and allusion. Moore was alert to irony and cognizant of how translation can mute the effect; thus he complained to his friend Édouard Dujardin in March of 1888 that in the French translation of Confessions of a Young Man "the irony of the English disappears... In English I have my tongue in my cheek, in French I am deadly serious"'.

5. Ford Madox Ford, "The Glacial Gaze of the Serpent", in The Bodley Head Ford Madox Ford V.5, ed. Michael Killigrew, London, The Bodley Head, 1971, p. 305-306.

6. Arthur Frank, The Wounded Storyteller: Body, Illness, Ethics, Chicago, University of Chicago Press, 1995, p. 161.

7. George Moore, Confessions of a Young Man, op. cit., p. 42.

8. John Eglinton [W.K. Magee], Irish Literary Portraits, 1935, Reprint, Freeport, New York, Books for Libraries, 1967, p. 96. Throughout his letters to Édouard Dujardin, Moore frequently laments his limitations as a writer and speaker of French, although he does not therein address his competence as a reader. See George Moore, Letters of George Moore to Ed. Dujardin, 1886-1922, ed. and trans. John Eglinton [W.K. Magee], Bournemouth, Sydenham, 1942.

9. George Moore, Letters of George Moore to Ed. Dujardin, 1886-1922, op. cit., p. 27. 
Knowledgeable readers of Rousseau have been widely divided among themselves on the matter of irony, of whether or not Rousseau deliberately rendered his younger self ridiculous, especially since the recollective voice frequently appears equally ridiculous. In contrast, the Moore who emerges at the end of Confessions and Hail and Farewell is a wiser figure whose initial enthusiasms have given over to more pragmatic attitudes and an agenda of hard work. His narrative persona rarely speaks from a static vantage point beyond the action of the text but rather narrates with the knowledge or the convictions held at the time of the past events he describes. The reader watches the persona develop as the story proceeds, although seldom to the point at which he writes the book we have in our hands. Early in Hail and Farewell, Moore contrasts his lifelong sense of inferiority to Rousseau's belief in his innate goodness and, in the process of doing so, addresses Rousseau's narrative positioning in relation to a past self, noting that "Rousseau realised in age that in youth Rousseau was a shy, silly lad, with no indication, apparently, of the genius that awaited him in middle life, always blundering, and never with the right word on his lips ${ }^{10}$ ". Ostensibly drawing a contrast, he also implies a parallel between himself and Rousseau, as his own persona often speaks under a guise of foolish naïveté that eventually gives way to a disenchanted wisdom. In reality, his comment more aptly describes his own Confessions than it does Rousseau's. Perhaps Moore is ignoring the lack of development in Rousseau's retrospective narrator, or his judgment may result from having never finished the book. As Adrian Frazier discovered in an unpublished letter of 1924, Moore acknowledged to Magee that he had never read the final third of the Confessions ${ }^{11}$. He was thus unacquainted with the grand tour of lies, contradictions, and self-delusions by which Rousseau proclaims his virtues and declares his tender, misunderstood heart all the way to his final pages.

So was Rousseau was truly an influence upon Moore in the 1880s? That is not a question with an easy answer, but we can say with great confidence that both men extend the range of autobiography and most especially the range of the confessional. Although confession has been the starting point for western autobiography since Augustine, Rousseau's Confessions is generally described as the first modern autobiography because of its exclusively secular orientation and its insistence that far from being prototypical of sinful humanity, its narrator is entirely unlike any other man and declares his work to be unlike any other work. In the famous opening sentences of The Confessions, Rousseau affirms confidently,

I have resolved upon an enterprise which has no precedent, and which, once complete, will have no imitator. My purpose is to display

10. George Moore, Hail and Farewell, ed. Richard Cave, Gerrards Cross, Colin Smythe, 1976, p. 100. 11. Adrian Frazier, George Moore, New Haven, Yale University Press, 2000, p. 488. 
to my kind a portrait in every way true to nature, and the man I shall portray will be myself.

Simply myself. I know my own heart and understand my fellow man. But I am made unlike any one I have ever met; I will even venture to say that I am like no one in the whole world. I may be no better, but at least I am different. Whether Nature did well or ill in breaking the mould in which she formed me, is a questions which can only be resolved after the reading of my book ${ }^{12}$.

In his focus on the individual and unreplicable self, Rousseau, as Lionel Gossman notes, rejected "the neoclassical discrimination of noble and base, high and low, public and private, tragic, and comic ${ }^{13}$ ". Descriptors such as base, low, private, and comic traditionally reference the arena of the body, and Rousseau broke new ground in the confessional mode by treating bodily matters, particularly sexuality, as a vital part of the story of his maturation. Although his manner of telling renders sexuality an often solitary and largely humiliating compulsion, he nevertheless confesses his sexual predilections and adventures as crucial aspects of his emergent sensibility rather than as merely low comedy or as sins repudiated and recalled only as reminders of God's grace in having rescued his soul from his body. So did Moore, who both spoke and wrote openly about the body as a tragicomic foil to human aspiration and who, as his friends and acquaintances complained, could fail to observe the accepted boundaries between public and private revelation. Advising the object of one of his many epistolary flirtations in a letter of 1910, Moore instructs her to "write your life but write it in detail; it is detail that is interesting in autobiography especially" and to "look into Jean-Ja[c] ques" before beginning ${ }^{14}$. Privileging detail as autobiography's most "interesting" element draws away from a notion of the autobiographical self as generalized, public and concerned with matters spiritual and intellectual, while potentially embracing that which is base, low, private, and comic. Readers of Moore will at once recall the bumbling sexual encounters of Confessions of a Young Man, the rapturous memories of his thinly-disguised love affair with Maude Cunard in Memoirs of My Dead Life (1906), and the advent of impotency (real or metaphorical) in Hail and Farewell. The sexual body is almost always a part of Moore's gossip about himself and others, and always part of the whole pattern of development in which he places his narrated life,

12. Jean-Jacques Rousseau, Confessions, trans. J.M. Cohen, New York, Penguin, 1953, p. 17.

13. Lionel Gossman, "The Innocent Art of Confession and Reverie", Daedalus, 107.3, 1978, p. 60.

14. George Moore to Emily Lorenz Meyer, 3 August 1910, George Moore on Parnassus (1900-1933 to Secretaries, Publishers, Printers, Agents, Literati, Friends, and Acquaintances), ed. Helmut Gerber, Newark, University of Delaware Press, 1988, p. 183. 
With family resemblance if not possible parentage thus established, let me now move specifically to matters of confession and ethics, for it is ethics that increasingly seems at issue in thinking about Moore. Confessions of a Young Man can be read as a text that structures itself along not only the tradition of the confession but one of autobiography's other primary models, the book of Exodus. Moore describes with rapture his deliverance, by means of "echo-augury" and his father's convenient premature death, to the promised land of Paris, a world of art and women far from the bogs of County Mayo. At its conclusion, financial exigencies and some innate sense of self-preservation deliver its narrator again, this time away from dangerous temptation of dilettantism so pitilessly mocked in Parnell and his Island's portrait of the Francophile would-be poet, "Landlord M--" and toward the lonely and assiduous labor of authorship in London. But while the story of beginnings (the Genesis) and in particular the story of deliverance (the Exodus) provide the underlying plot structure of the book, Confessions of a Young Man must also be read as its title commands. Moore's autobiographical narrator confesses to many dreadful things: killing cats as a child (and he was fond of cats as an adult), secret relief at the death of an admirable and formidable parent whose passing set him free financially, self-centered horror that "some wretched farmers and miners refuse to starve that I may not be deprived of my demitasse at Tortoni's, my cat and my python ${ }^{15}$, , his later inadequacy and indifference as a lover, his exacerbation of a quarrel that separated him forever from his brother Maurice, and the deliberate avoidance of his mother's deathbed.

In Hail and Farewell, he also recollects the charwoman described in Confessions of a Young Man as "awful Emma" and admits that in recognition of the years she served him in the Temple, he left her a disgracefully meagre tip and later forgot to assist her in her old age when solicited to do so by her son. The narrator's neglect of Emma may seem less significant over the course of a life than does avoiding one's mother's deathbed, but it is this last incident of which Moore says, "this confession costs me as much as some of Rousseau's cost him ${ }^{16 "}$. The story parallels and yet distinctly contrasts with the most notorious event of Rousseau's Confessions: the theft of the pink and silver ribbon, an act for which the young Rousseau successfully shifted blame to a pretty servant girl who, as he imagines, was as a consequence likely condemned to a life of "disgrace and misery" being now without a character reference and branded a thief ${ }^{17}$.

Paul de Man's provocative reading of Rousseau from his early book Allegories of Reading provides an especially useful perspective from which to analyze Moore's failure to attend to his downtrodden servant, as well his rejection of Clara Chris-

15. George Moore, Confessions, op. cit., p. 123.

16. George Moore, Hail and Farewell, op. cit., p. 103.

17. Jean-Jacques Rousseau, Confessions, op. cit., p. 86. 
tian (the "Stella" of Hail and Farewell) and his avoidance of his mother's death bed as recounted in Memoirs of My Dead Life. The confession, de Man claims, holds the revelation of truth as its only act; it is epistemological, having knowing at its center and neutral in moral quality. Judgment follows the confession and is a task left to the listener, the reader, or the part of the self which hears the confession of the other part. The excuse, on the other hand, presupposes and predetermines judgment (in Rousseau's case, a verdict of "not guilty") and is thus concerned with questions of good and evil rather than matters of fact ${ }^{18}$. In the case of the stolen ribbon, Rousseau declares that he has regretted the act all his life and seeks relief in telling his secret on the pages of his book. But his confession of the deed is framed by a rhetorical performance in which he insists that the act was motivated by affection because he loved Marion and wished to receive a ribbon from her and was thinking of her when he was so accused; additionally, the act contributed to his later moral development. Although he asserts in his first paragraphs that judgment must be restrained until "after the reading of my book", he offers his confession as evidence of his righteousness. As de Man observes, "its purpose is not to state but to convince ${ }^{19}$.

The excuse, then, is a species of self-referential figurative rhetoric which inverts, Ben Roth explains, "the essential form of the confession this is what happened and I feel guilty to I'm not guilty (although I feel so) because this is what happened ${ }^{20}$ ". Additionally, Rousseau suggests that guilt is merely a sign of a pure heart and that a pure heart stands independent of one's bad actions. Early in the text, he clarifies what he calls "the one great maxim of morality": the avoidance of situations in which our duties are in opposition to our interests. "In such situations", he writes, "however sincere and virtuous the motives we start with, sooner or later and unconsciously we weaken, and become wicked and unjust in practice, though still remaining good and just in our hearts ${ }^{21}$ ". Thus another way of seeing this syntactical inversion might be as a shift from although my heart was pure, my actions were bad, and thus I am guilty to I am not guilty, although my actions were bad, because my heart is pure. The confessions of Moore's fictional characters, like those of his autobiographical persona, follow a different pattern. When Father Gogarty of The Lake exchanges letters with Nora Glynn, he confesses to himself by confessing to her, and he learns to know and understand himself, a process much more important than whatever Nora Glynn thinks of him. Albert

18. Paul de Man, Allegories of Reading: Figural Language in Rousseau, Nietzsche, Rilke, and Proust, New Haven, Yale University Press, 1979, p. 278-301.

19. Ibid., p. 281.

20. Ben Roth, "Confessions, Excuses, and the Storytelling Self: Rereading Rousseau with Paul de Man", Institut für die Wissenschaften vom Menschen. Junior Visiting Fellows' Conferences. Vol. XXXII.

21. Jean-Jacques Rousseau, Confessions, op. cit., p. 61-62. 
Nobbs reveals her great secret to the empathetic but sleepy Hubert Page because she is lonely, not because she seeks judgment for good or bad. When Moore's most celebrated character, Esther Waters, tells her story to Mrs. Barfield at the book's conclusion, the story appears to have no motive beyond its own telling as a history of her life since leaving Woodview. The story lacks the structure of the excuse in that justifications neither precede nor follow it. Whether the function of the story-telling is self-analysis, as in the case of Father Gogarty, or the sharing of information, as in the case of Albert Nobbs and Esther Waters, none of these fictional characters neither seek to persuade his or her interlocutor concerning the moral quality of the actions thus narrated.

The motives and the correspondent structure of Moore's autobiographical confessions, however, lie somewhere in-between the open-ended tales of his fictional characters and the excuses of Rousseau. Their moral quality remains uncertain; their revelation may "cost" the autobiographical narrator, to invoke Moore's term, in some ways and not in others. Before addressing the story of the neglect of "awful Emma", the memory that Moore identifies as particularly "costly", I want to look first at two other betrayals. Both involve women he loved and who loved him. In the final volume of Hail and Farewell, the narrator relates the story of his parting from Clara Christian, the English painter whom he took away from her companion and brought with him to Dublin, installed in a house just far enough away from Lower Ely Place to maintain respectability and privacy. Moore also treated this situation in his 1903 short story, "The Wild Goose", in which Ned, a repatriated Irish writer, marries a local woman only to abandon her and their son soon after. Disenchanted with a nation dominated by repressive and anti-intellectual religion, he reasons that to stay would require that "he would have come to accept all the base moral coinage in circulation". However, Ned is sufficiently self-aware to acknowledge that in addition to whatever other arguments he may produce, he simply no longer loves and desires his wife: "the sensual coil that had bound them was broken; once more he was a free man". Looking back toward Howth from the boat to England, he is "at one moment ashamed of what he had done, at the next overjoyed that he had done $\mathrm{it}^{22}$ ". The ideological basis for his withdrawal (an excuse after de Man's definition) is undermined by his admission that he no longer finds Ellen sexually attractive (a fact, or morally neutral reason).

Within a year of the story's first publication in English, Moore and Clara Christian had parted. The break with "Stella" in Hail and Farewell draws directly from the language of the short story, further suggesting that Ned's rejection of his wife bears some relation to Moore's rejection of Christian and that Moore saw

22. See George Moore, "The Wild Goose”, in The Untilled Field, Gerrards Cross, Colin Smythe, 1976, p. 280, p. 271. I am grateful to Adrian Frazier for suggesting to me the parallel between Ned's rejection of Ellen and Moore's rejection of "Stella". 
"The Wild Goose" as an early version of what would later become an even more confessional narrative. In the context of the argumentative trajectory of Hail and Farewell, the narrator's failure to love and his avoidance of their bed follows as a consequence of lingering too long in the land of the "priest, the nun and the $\mathrm{ox}^{23}$ " and as further evidence that Ireland is itself impotent and sterile. Yet that rationale, or causal account, is not the one directly stated; it can only be surmised by analysis of the event's importance in the book's overall argument. Instead, the narrator flounders about searching for a reason, if not a justification, but finally, none exists. The ideological grounds for his lack of love are in practical terms, absurd. Despite the incident's important role in the rhetoric of Hail and Farewells repudiation of Ireland as a fertile ground for an artistic and cultural renewal, it resonates most poignantly as painful admission of inexplicable neglect and the failure to care sufficiently for another human being.

People fall out of love every day, sometimes as inexplicably as the autobiographical narrator of Hail and Farwell falls out of love with "Stella". Many also dread the agonizing moments of a parent's last days, as Moore recalls his dread of his mother's deathbed in the final section of Memoirs of My Dead Life. John Barbour has suggested that "a writer with good judgment... recognizes that moral agency is circumscribed, and there is much in any life... that is beyond one's control... Certain actions may be neither simply voluntary nor involuntary, and might provide moral excuses that diminish a person's responsibility without entirely eliminating it $^{24}$ ". Barbour's usage of the term excuse differs greatly from de Man's, and that difference is telling in light of the moral significance of Moore's endeavor. Through its self-mocking comedy, Hail and Farewell reduces Rousseau's model of the excuse to absurdity while retaining the narrator's uneasy sense of guilt over ceasing to love, an action which "may be neither simply voluntary nor involuntary". When Moore approaches the subject of his mother's death in Memoirs of My Dead Life, he first attempts a self-justifying excuse for his terror of her death-bed: that he has a superior imagination and is thus both more troubled by apprehension of the scene and more sympathetic to those whose sensibilities differ from the norm, unlike those who would condemn him as "hard and selfish $^{25}$ ". Yet as "Resurgam" continues, it develops into an extended meditation on the nature of grief and on the reality of human selfishness. Thinking of a passionate love affair which had just ended, he admits that "a man cannot lament two women at the same time" and finds himself dwelling on the loss of the young woman rather than the old:

23. George Moore, Hail and Farewell, op. cit., p. 608.

24. John D. Barbour, "Judging and Not Judging Parents", in Paul John Eakin (ed.), The Ethics of Life Writing, Ithica, Cornell University Press, 2004, p. 91.

25. George Moore, Memoirs of My Dead Life, London, William Heinemann, 1906, p. 298. 
I began to consider that shameful injustice is undoubtedly a part of our human lot... Why, I asked myself, as a I lay under the larches, are we to mourn transitory delight so intensely, why should it possess us more entirely than the sorrow that we experience for her who endured the labor child-bearing, who nourished us perchance at her breast, whose devotion to us was unceasing, and who grew kindlier and more divorced from every thought of self as the year went by? From injustice there can be no escape, not a particle ${ }^{26}$.

If selfishness is "part of our human lot" it might function as what Barbour calls a "moral excuse". Yet Moore is rigorous in his judgment, regardless of whether such a trait derives from what he would call our "instinct' or nature. As a confession rather than an excuse, his claim, although selfishness is part of our human lot, I was indeed selfish, and thus I am guilty, follows the syntactical pattern I have identified within de Man's analysis of the genuine confession: although my heart was pure, my actions were bad, and thus I am guilty.

One last confession of neglect requires consideration, that of "awful Emma", the oppressed and overworked English charwoman who cleaned his spartan lodgings during the years after he had regretfully left his youth in Paris for a regime of disciplined labor in of London. Moore maintains that the confession of his failure to leave Emma an adequate tip or to help her in her old age cost him a great deal. But in what ways? His neglect deprived Emma of money that she very much needed and made her old age more difficult, but his life was not altered in the slightest degree. Similarly, the damage Rousseau brought upon Marion the servant girl was devastating to her, but had a negligible effect on his fortunes. As he acknowledges, without a letter of reference and branded as a thief Marion would have few options beyond prostitution, begging, crime, or hard labor at the very bottom of the social ladder, whereas his crime cost him very little, as the household in which he had been employed was already in the process of dismantlement.

If the acts so confessed were without repercussions to either man, what of the confession itself? Rousseau insists that his benign motivation and the importance of such a deed in the development of his sensibility far outweighs whatever harm resulted from this and other similarly questionable actions, such as exposing himself to young girls, abandoning a travelling companion writhing in the throes of an epileptic seizure, and depositing five children born out of wedlock at the gates of a foundling institution. Such deeds cost the narrator nothing precisely because, despite his frequent claims that the reader shall judge him, he has already judged himself and found himself innocent. Published posthumously at 
his request, his confessions did little to combat Voltaire's accusations in his anonymous pamphlet "Sentiment des Citoyens" (1764) that Rousseau was a creature of inanity, indecency, megalomania, ingratitude, and debauchery. Yet his reputation as a human being was already sullied before Voltaire published his attack, and his writings only grew in popularity and influence as if immune from charges against his person.

Could it be, then, that when Moore asserts that "this confession costs me as much as some of Rousseau's cost him", he is in fact saying that his confession cost him nothing? In order to address this question, we must recall one of the most striking features of Moore's autobiographies: his acute and prescient understanding of the distinction among the public figure of the author, the human being who writes, the voice we hear narrating a story, and in the case of autobiography, the man depicted in that story. In advertisements for Moore's fiction after the mid-1890s, he is repeatedly identified as the "author of Esther Waters", as he is in reviews and interviews for decades after its publication. His sympathetic treatment of an illiterate servant who raises her fatherless child against all odds brought him not only commercial success but a begrudging recognition what might be called his social conscience. Although he enjoyed public provocation, he was neither a clown nor a libertine and was sincerely disturbed by the limited and often desperate conditions in which the poor - and particularly impoverished women and children - endured their lives. The success of Esther's efforts to keep her child depend upon her ability to earn sixteen rather than fourteen pounds annually, and Moore's confession in Hail and Farewell acknowledges that "the author of Esther Waters" could be as destructive in his neglect as some of Esther's employers were in their outright hostility. The balance between seriousness and scandal that Moore maintained as a public figure is dangerously undermined by such a confession. At the same time, Moore's knowledge that a servant's life can be radically altered by a small sum renders this confession the expression not only of an abashed public author but a man censured by his own conscience.

In these instances of revelation, both very much confessions rather than excuses or even reasons, Moore walks an ethical tightrope. Insistent on the essential rightness of his life's pilgrimage to Parnassus, he was also willing to acknowledge that the way was not only "a hard fight", as Esther Waters characterized her life experience $^{27}$, but a path strewn with his betrayals and his failure to care enough: for his parents, his brother, for Clara Christian, and even for awful Emma. He admired (and sometimes plagiarized) Dostoevsky's assertion that a man who knows he is ridiculous cannot really be ridiculous, and perhaps it is true that a man who knows he loves insufficiently is a man who understands love. As a satirist of

27. George Moore, Esther Waters, op. cit., p. 400. 
himself, as well as others, Moore raises in his autobiographical writings ethical problems that he could not solve and allows the reader the knowledge of his stalemate. Another great Russian, Anton Chekov, declared that a good writer is not as one who declares that horse-stealing is wrong but instead depicts convincingly the mind of the horse-stealer. If Chekov is correct, then Moore has given the reader knowledge in the place of excuses, in keeping with his achievement as a consummate writer of the self in its labors, its accomplishments, and its confessions. 